Lect. univ. dr. Bogdan Dima

Facultatea de Drept, Universitatea din București

Președinte Asociația Centrul pentru Analize Strategice

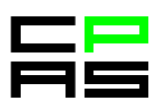

\title{
Cât de militară este ordonanța militară?
}

Rezumat: În acest articol voi analiza natura juridică a ordonanțelor militare emise de către Ministrul afacerilor interne pe perioada stării de urgență, în conformitate cu Ordonanța de Urgență nr. 1/999 privind regimul stării de asediu și regimul stării de urgență (OUG nr. 1/1999). Sfatul meu este să nu ne lăsăm păcăliți de termenul „militar”. De fapt, ordonanțele militare emise pe durata stării de urgență de către Ministrul afacerilor interne sunt acte administrative normative, care pun în executare prevederile OUG nr. 1/1999. Ca atare, legalitatea lor poate fi contestată în fața instanțelor judecătorești de contencios administrativ, dar nu pot fi suspendate în conformitate cu art. 5 alin. 3 din Legea contenciosului administrativ nr. 554/2004.

Cuvinte cheie: ordonanță militară, Ministrul afacerilor interne, control judecătoresc, acte administrative

\section{How `Military`Is a Military Ordinance?}

Abstract: In this article, I shall discuss the legal nature of the military ordinances issued by the Minister of Internal Affairs during the state of emergency, in accordance with Emergency Ordinance no. 1/1999 concerning the regime of the state of siege and the regime of state of emergency (EOG no. 1/1999). My advice is that no one should not fall for the term "military”. In fact, military ordinances issued during the state of emergency by the Minister of Internal Affairs are normative administrative acts facilitating the execution of EOG no. 1/1999 provisions. As a result, they could be contested for legality in front of the judiciary, but they cannot be suspended, in accordance with art. 5 para. 3 of the Law no. 554/2004 concerning the judiciary control over the administrative acts.

Key words: military ordinance, Minister of Internal Affairs, judiciary control, administrative acts

\section{I. Întrebări multe, explicații puține}

În spațiul public au fost formulate puține explicații serioase cu privire la natura juridică și efectele ordonanțelor militare emise în timpul stării de urgență. Care este natura juridică a ordonanței militare emise de Ministrul afacerilor interne în timpul stării de urgență? Este posibil să stabilești prin ordonanță militară măsuri care prevăd restrângerea exercițiului unor drepturi și libertăți fundamentale prevăzute în Constituție? Care sunt garanțiile pe care le au cetățenii 
Lect. univ. dr. Bogdan Dima

Facultatea de Drept, Universitatea din București

Președinte Asociația Centrul pentru Analize Strategice

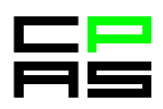

împotriva aplicării abuzive de către autoritățile publice a dispozițiilor din aceste ordonanțe militare?

Astfel de întrebări ar putea să fie considerate de unii sau de alții drept aberații în situații de criză gravă, conform principiului arhicunoscut „țara arde și baba se piaptănă”. Cu toate acestea, am convingerea că astfel de subiecte trebuie explicate până sunt înțelese. Pe de o parte, nu trebuie lăsat loc dubiului și neîncrederii în rândul cetățenilor cu privire la măsurile dispuse de autorități în timpul stării de urgență. Pe de altă parte, autoritățile trebuie să înțeleagă limitele până la care pot lua decizii de restrângere a exercițiului unor drepturi și libertăți raportat la situația de fapt existentă și la necesitatea salvării pentru viitor a unei societăți democratice.

Inclusiv în situații excepționale, respectarea conduitei stabilite prin actele autorităților publice este mai eficientă când cetățenii înțeleg ce se cere de la ei și care este modalitatea prin care se cere să facă sau să nu facă ceva. Astfel, dacă se impun restrângeri necesare ale exercițiului unor drepturi și libertăți pe perioadă determinată, cred că este decent ca cetățenii să înțeleagă ce este actul juridic prin care se dispun restrângerile respective, dar și cum se pot proteja de abuzurile care ar rezulta din aplicarea respectivului act juridic.

Dacă aceste elemente nu sunt clar explicate și nu sunt bine înțelese, cetățenii vor fi circumspecți, speriați și deloc predispuși să își adapteze conduita după cum prevăd normele juridice. Chiar și în stare de urgență, nu suntem barbari. Nu acționăm după bunul plac și nu stabilim reguli proprii de comportament. Suntem și trebuie să rămânem în continuare parte a unei societăți democratice organizate în stat.

II. Care este natura juridică a ordonanței militare emisă de Ministrul afacerilor interne în timpul stării de urgență

Pentru a califica în mod exact ce fel de act juridic este ordonanța militară, trebuie să vedem cine este emitentul actului și care este conținutul respectivului act.

Din perspectiva emitentului actului, lucrurile sunt clare: ordonanța militară este emisă de Ministrul afacerilor interne, cu acordul prim-ministrului. Deci, ordonanța militară este un act administrativ emis de o autoritatea a administrației publice centrale în temeiul unor dispoziții legale (OUG nr. 1/1999 adoptată prin Legea nr. 453/2004) și al prevederilor decretului prezidențial privind instituirea stării de urgență (Decretul nr. 195/2020).

Din perspectiva conținutului actului, lucrurile nu mai sunt chiar așa simple și pot apărea confuzii voite sau involuntare în interpretare. Dacă analizăm conținutul celor trei ordonanțe militare care au fost emise de la momentul instituirii stării de urgență până în prezent, vom observa că acestea cuprind măsuri administrative în sarcina anumitor autorități și instituții ale statului, dar și măsuri de restrângere a exercițiului unor drepturi și libertăți fundamentale (de ex., interzicerea circulației tuturor persoanelor în afara locuinței/gospodăriei, cu o serie de excepții). 
Lect. univ. dr. Bogdan Dima

Facultatea de Drept, Universitatea din București

Președinte Asociația Centrul pentru Analize Strategice

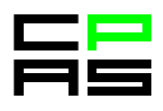

Însă, în conformitate cu art. 53 din Constituția României, exerciţiul unor drepturi sau al unor libertăţi poate fi restrâns numai prin lege și doar pentru anumite situații (sănătatea publică fiind una dintre aceste cauze). Mai mult, art. 4 din OUG nr. 1/1999 prevede că, pe durata stării de urgență, exercițiul unor drepturi și libertăți fundamentale poate fi restrâns, cu câteva excepții (de ex., dreptul la viață), numai în măsura în care situația o cere și cu respectarea art. 53 din Constituția României. Ca atare, având în vedere cele expuse mai sus, pentru a putea definitiva răspunsul la întrebarea privind natura juridică a ordonanței militare, trebuie să înțelegem exact ce anume poate prevedea în conținutul său.

III. Dacă ordonanța militară este act administrativ emis de Ministrul afacerilor interne, deci nu este lege, poate să reglementeze măsuri de restrângere a exercițiului unor drepturi și libertăți constituționale?

Ei bine, răspunsul juridic la întrebarea de mai sus este că, de fapt, ordonanța militară nu stabilește prin ea însăși reglementări primare, de rang legal, care reglementeză restrângerea exercițiului unor drepturi și libertăți constituționale. Ordonanța militară, ca act administrativ, nu face altceva decât să organizeze executare/să pună în aplicare, prin raportare la situația de fapt existentă, dispozițiile de rang legal din OUG nr. 1/1999 adoptată de Parlament prin Legea nr. $453 / 2004$.

Astfel, în art. 20 din OUG nr. 1/1999 sunt prevăzute, cu forță juridică de lege, măsuri care pot fi luate în caz de stare de urgență și prin care se pot restrânge exercițiul drepturilor și libertăților constituționale ale cetățenilor. Mai mult, legea de aprobare a OUG nr. 1/1999 a fost adoptată de Parlament în 2004, moment în care conținutul normativ al ordonanței de urgență a devenit conținutul normativ al unei legi adoptate de Parlament.

Să luăm un exemplu pentru a înțelege mai bine argumentul juridic. De exemplu, la art. 20 lit. c din OUG nr. 1/1999 se stabilește cu titlu general că autoritățile publice pot să limiteze sau să interzică circulația vehiculelor sau a persoanelor în anumite zone ori între anumite ore și să elibereze, în cazuri justificate, permise de liberă circulație. La pct. 3 din Anexa II a Decretului nr. 195/2020 privind instituirea stării de urgență se stabilește, tot cu titlu general, o măsură de primă urgență cu aplicabilitate graduală: „limitarea sau interzicerea circulației vehiculelor sau a persoanelor în/spre anumite zone ori între anumite ore, precum și ieșirea din zonele respective". În vederea punerii în executare a acestor dispoziții de rang legal din OUG nr. 1/1999 și de rang administrativ din decretul prezidențial pentru instituirea a stării de urgență, Ordonanța militară nr. 3/20202 emisă de Ministrul afacerilor interne, printre altele, a restricționat în concret și circulația în afara locuinței/gospodăriei a persoanelor care au împlinit vârsta de 65 de ani, mai puțin în intervalul orar 11.00-13.00 și cu excepția unor motive urgente (de ex., deplasarea pentru asistență medicală care nu poate fi amânată și nici realizată de la distanță).

Așadar, ordonanța militară emisă în stare de urgență nu este nimic altceva decât un act administrativ, subsecvent legii, prin care se stabilește în concret măsura efectivă care urmează să 
Lect. univ. dr. Bogdan Dima

Facultatea de Drept, Universitatea din București

Președinte Asociația Centrul pentru Analize Strategice

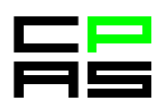

fie aplicată situației de fapt existente. Ceea ce înseamnă că, inclusiv din perspectiva conținutului ordonanței militare, aceasta are natura juridică a unui act administrativ cu caracter normativ, emis în vederea punerii în aplicare a dispozițiilor de rang legal cuprinse în OUG nr. 1/1999 și în conformitate cu decretul Președintelui privind instituirea stării de urgență.

Dacă înțelegem și acceptăm acest argument juridic, înțelegem și faptul că restrângerea exercițiului drepturilor și libertăților în stare de urgență nu este dispusă de Ministrul afacerilor interne sau de Președintele României, ci este prevăzută într-o lege, anume OUG nr. 1/1999 adoptată prin Legea nr. 453/2004 a Parlamentului. Ca atare, instituirea unor măsuri concrete de restrângere a drepturilor și libertăților fundamentale prin ordonanțe militare nu poate reprezenta în sine o încălcare a uneia dintre condițiile prevăzure la art. 53 din Constituția României, pentru că, de fapt, posibilitatea de a restrânge exercițiului unor drepturi este dispusă prin lege (OUG nr. 1/1999 adoptată prin Legea nr. 453/2004), iar nu prin actele administrative subsecvente respectivei legii, care doar o pun în executare. Cel mult, în condițiile în care prin ordonanță militară se dispun restrângeri ale exercițiului unor drepturi și libertăți care nu se încadrează la măsurile generale prevăzute de art. 20 din OUG nr. 1/1999, atunci ordonanța militară ar fi nelegală, întrucât nu se mai încadrează în limitele prevăzute de lege și reglementează cu exces de putere.

IV. Care sunt garanțiile pe care le au cetățenii împotriva aplicării abuzive de către autoritățile publice a dispozițiilor din aceste ordonanțe militare?

Dacă am stabilit natura juridică a ordonanței militare de act administrativ normativ emis pentru punerea în aplicare/executarea dispozițiilor legale aplicabile în stare de urgență, pasul următor vizează identificarea garanțiilor legale pentru protejarea cetățenilor împotriva aplicării abuzive a dispozițiilor prevăzute în ordonanțele militare.

Pentru a oferi un răspuns la această întrebare trebuie să vedem în ce măsură ordonanța militară, ca act administrativ normativ, se încadrează sau nu într-una dintre categoriile de acte exceptate de la controlul în contencios administrativ. Conform art. 126 alin. 6 din Constituție și art. 5 alin. 1 din Legea contenciosului administrativ, sunt exceptate de la controlul pe calea contenciosului administrativ actele care privesc raporturile cu Parlamentul, precum şi actele de comandament cu caracter militar. În art. 2 lit. lit. $\mathrm{k}$ și I din Legea contenciosului administrativ sunt definite expres atât actele care privesc raporturile cu Parlamentul, cât și actele de comandament cu caracter militar.

Astfel, actele care privesc raporturile cu Parlamentul sunt acele acte emise de o autoritate publică, în realizarea atribuțiilor sale, prevăzute de Constituție sau de o lege organică, în raporturile de natură politică cu Parlamentul. De exemplu, poate fi considerat act emis de o autoritate publică în raporturile de natură politică cu Parlamentul decretul Președintelui privind desemnarea unui candidat la funcția de prim-ministru. Ar exista câteva argumente în favoarea ideii că însuși decretul Președintelui privind instituirea stării de urgență ar fi un act al unei 
Lect. univ. dr. Bogdan Dima

Facultatea de Drept, Universitatea din București

Președinte Asociația Centrul pentru Analize Strategice

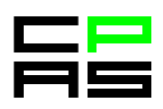

autorități publice în raporturile cu Parlamentul, ca urmare a faptului că starea de urgență pe care o instituie este încuviințată ulterior de Parlament. Însă, despre acest subiect voi scrie cu altă ocazie, pentru că necesită o analiză mai aprofundată.

Actele de comandament cu caracter militar sunt cele referitoare la problemele strict militare ale activității din cadrul forțelor armate, specifice organizării militare, care presupun dreptul comandanților de a da ordine subordonaților în aspecte privitoare la conducerea trupei, în timp de pace sau război ori, după caz, la îndeplinirea serviciului militar. De exemplu, ordinul privind dispunerea trupelor terestre în poziție de apărare în cazul unei agresiuni armate este un act de comandamanet cu caracter militar. Însă, actele prin care se dispun măsuri administrative de organizare și funcționare în cadrul structurilor militare (ridicare în grad) nu sunt acte de comandament cu caracter militar. $\mathrm{Cu}$ alte cuvinte, nu toate actele administrative ale "Armatei" sunt acte de comandament cu caracter militar, ci doar acelea care presupun un drept de comandă militară efectivă.

În plus, în art. 5 alin. 3 din Legea contenciosului administrativ se prevede expres faptul că în litigiile referitoare la actele administrative emise pentru aplicarea regimului stării de urgență nu sunt aplicabile prevederile art. 14 din aceeași lege. În art. 14 se prevede posibilitatea ca, în anumite condiții prevăzute de lege, persoana care se consideră vătămată într-un drept sau interes legitim propriu să poată cere suspendarea executării actului administrativ vătămător până la pronunțarea instanței de fond. Analizând cele două articole împreună rezultă că actele administrative emise pentru aplicarea stării de urgență nu pot fi suspendate de instanța de contencios administrativ, însă instanța poate verifica legalitatea respectivelor acte și poate dispune anularea în tot sau în parte ori menținerea acestora.

Fără a intra în și mai multe argumente juridice, concluzia este relativ simplă dacă acceptăm rațiunea argumentului juridic: faptul că ordonanțele militare cuprind în denumirea lor termenul de „militar" nu le califică automat pe toate ca fiind acte de comandament cu caracter militar. Conținutul lor efectiv trebuie avut în vedere pentru a le califica fie acte de comandament cu caracter militar, fie acte administrative pentru aplicarea stării de urgență. În situația în care ordonanța militară ar cuprinde și dispoziții de comandament cu caracter militar, și măsuri administrative de punere în aplicare a dispozițiilor OUG nr. 1/999, ordonanța ar intra tot în categoria actelor administrative pentru aplicarea stării de urgență, dar acele dispoziții de comandament cu caracter militar din conținutul său nu ar putea deveni obiect al unui litigiu în contencios administrativ.

Astfel, dacă prin conținutul lor nu reflectă ordine de comandă militară efectivă, în sens restrâns, atunci ordonanțele militare sunt o categorie de acte administrative normative supuse controlului în contencios administrativ, fără posibilitatea suspendării efectelor acestora până la momentul soluționării definitive a cauzei.

Însă, chiar dacă argumentul juridic prezentat mai sus este rațional și obiectiv, acest lucru nu înseamnă că aplicarea eventuală în practică a acestuia va avea loc în mod efectiv. Este posibil, 
Lect. univ. dr. Bogdan Dima

Facultatea de Drept, Universitatea din București

Președinte Asociația Centrul pentru Analize Strategice

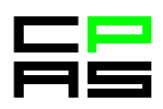

chiar probabil, ca instanțele de contencios administrativ să fie foarte reticente cu privire la potențialele cereri de anulare a ordonanțelor militare (desigur, dacă vor exista astfel de cereri!). Vor tinde să caute orice alt argument juridic pentru a scăpa de responsabilitatea imensă pe care o implică analiza pe fond și soluționarea unui astfel de litigiu. Nu m-aș mira dacă, puse în fața unei cereri de anulare a dispozițiilor dintr-o ordonanță militară pe motiv că acestea încalcă drepturile și interesele legitime ale unei persoane, instanțele noastre vor considera că ordonanța militară este un act administrativ exceptat de la controlul în contencios administrativ pentru că este un act de comandament cu caracter militar, pentru simplul motiv că poartă denumirea de „ordonanță militară”. Sau, chiar mai rău, instanța va considera că este un act al unei autorități publice în raporturile cu Parlamentul pentru simplul motiv că starea de urgență a fost încuviințată de Parlament, conform Constituției. Ca atare, orice act administrativ subsecvent decretului prezidențial privind instituirea stării de urgență încuviințate de Parlament capătă și el caracterul de act administrativ al unei autorități publice în raporturile cu Parlamentul.

Oricât de absurde ar părea aceste argumente pentru un jurist, ele nu trebuie ignorate. Realitatea surprinde întotdeauna și viitorul este plin de necunoscute.

\section{Concluzii}

Ordonanțele militare nu sunt acte de comandament cu caracter militar doar pentru că poartă în titlu termenul de „militar”. Raportându-ne la conținutul celor trei ordonanțe militare emise până în acest moment, acestea sunt acte administrative normative emise pentru aplicarea regimului stării de urgență, adică pun în executare/fac aplicabile în concret dispozițiile de rang legal cuprinse în OUG nr. 1/1999 și preluate în decretul prezidențial privind instituirea stării de urgență.

Chiar dacă starea de urgență poate presupune restrângerea exercițiului unor drepturi și libertăți, aceasta nu înseamnă că cetățenii nu mai au garantat accesul liber la justiție și, totodată, posibilitatea de a se proteja împotriva măsurilor abuzive de punere în aplicare a măsurilor dispuse de autoritățile publice. Această garanție este oferită de art. 5 alin. 3 din Legea contenciosului administrativ. Totuși, această garanție nu trebuie doar să existe. Trebuie să fie și efectivă.

Existența și efectivitatea unor astfel de garanții fac diferența dintre o stare de urgență într-o societate democratică și situația normală dintr-o societate totalitară sau autoritară. De bine de rău, în România stării de urgență suntem încă într-o societate democratică și trebuie să rămânem în aceste limite dacă vrem să mai avem o șansă la normalitate după încheierea prezentei crize. În joc nu sunt numai drepturile și libertățile noastre acum, ci și drepturile și libertățile noastre în viitor.

* Nici nu am mai insistat asupra faptului că în 1999, atunci când a fost adoptată OUG nr. 1/1999, Poliția era încă o structură militarizată a statului. Deci, era logic să fie utilizată sintagma 
Lect. univ. dr. Bogdan Dima

Facultatea de Drept, Universitatea din București

Președinte Asociația Centrul pentru Analize Strategice

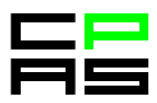

„ordonanță militară”. Mai mult, în varianta inițială a OUG nr. 1/1999 se prevedea expres și faptul că ordonanța militară are putere de lege. În 2004, când a fost adoptată OUG nr. 1/1999 cu modificări și completări prin Legea nr. 453/2004, termenul de ordonanță militară s-a păstrat deși Poliția nu mai era o structură militarizată, iar ordonanța militară a devenit obligatorie, fără a mai avea forță de lege (cum este și normal, conform Constituției României).

Materialul a fost publicat pe G4media.ro și preluat ulterior în revista online a Facultăţii de Drept, AUBD - Forum juridic $n r 1 / 2020$. 